\title{
TEOLOGICZNO-EKLEZJALNE ASPEKTY BIERZMOWANIA W ŚWIETLE PROGRAMU DUSZPASTERSKIEGO KOŚCIOŁA W POLSCE NA LATA 2017-2019
}

\section{THEOLOGICAL AND ECCLESIAL ASPECTS OF CONFIRMATION IN LIGHT OF THE CHURCH'S PASTORAL PROGRAM FOR 2017-2019 IN POLAND}

\begin{abstract}
A bstract. Theological and ecclesial aspects of confirmation Summary Considering the post-conciliar approach to sacramentology based on the idea of the Church of Christ as a living history of salvation, the article presents the sacrament of confirmation in its ecclesiological aspect. First, it draws attention to the sacrament of Christian maturity in the aspect of the Church's stability as the people of God. In the next paragraph it focuses on the participation of those who have accepted the sacrament of confirmation in the apostolic tasks of God's people, emphasizing in particular their taking full responsibility for the fate of the Church. The climax of the article is the depiction of the modern world's evangelization by enriching the world with a new ideal of holiness according to the Kingdom of God, which through Christ in the power of the Holy Spirit is constantly increasing among people until the final fulfillment in God who will be ,all in all” (see 1 Cor 15:24.28).
\end{abstract}

Key words: Christian initiation; Christ; Church; Holy Spirit; confirmation; apostolate; renewal of the world; God's kingdom.

Jednym z zasadniczych celów Programu duszpasterskiego Kościoła w Polsce na lata 2017-2019 jest odkrycie osoby i działania Ducha Świętego. Dotyczy to również pogłębienia teologicznego wymiaru sakramentu bierzmowania w sakramentalnej strukturze Kościoła. Zawsze mamy bowiem do czy-

Prof. dr hab. Marian KowalczyK, SAC, pracownik Katedry Teologii Dogmatycznej w Instytucie Nauk Teologicznych Wydziału Teologicznego Uniwersytetu Kardynała Stefana Wyszyńskiego w Warszawie; e-mail: mkowalczyk@sac.org.pl; ORCID: http://orcid. org/0000-0002-7006-4144. 
nienia z sakramentami „przez Kościół”, ponieważ jest on sakramentem działania Chrystusa, który dokonuje w nim swego zbawczego dzieła dzięki posłaniu Ducha Świętego, a także z sakramentami „dla Kościoła”, ponieważ budują one Kościółํ. Bierzmowanie jawi się jako sakramentalna Pięćdziesiątnica Kościoła lokalnego, a więc swoiste uobecnienie zesłania Ducha Świętego. Nawiązując do tradycji patrystycznej, Sobór Watykański II uwydatnia związek bierzmowania z inicjacją chrześcijańską.

Realizując wspomniany program duszpasterski dla Kościoła w Polsce, koncentrowano się na zadaniach ochrzczonych i bierzmowanych w mocy Bożego Ducha. Człowiek, który stał dotąd poza wspólnotą pełnoprawnych członków ludu Bożego, przez chrzest z wody i Ducha Świętego, dopełniony w darze Ducha przez bierzmowanie oraz Eucharystię, w której istotną rolę odgrywa epikleza Ducha, nawiązuje sakramentalny kontakt z Chrystusem i Kościołem² oraz podejmuje zadanie ewangelizowania świata. Mając to na uwadze, w podejmowanych wywodach zaprezentujemy teologiczno-eklezjalny aspekt bierzmowania.

\section{BIERZMOWANIE W ASPEKCIE TRWAŁOŚCI KOŚCIOŁA JAKO LUDU BOŻEGO}

Posoborowe ujęcie teologiczne sakramentologii, oparte na idei Kościoła chrześcijańskiego jako żywej historii zbawienia zarówno każdej osoby, jak i całego ludu Bożego, pozwala stwierdzić, że eklezjalny aspekt sakramentu bierzmowania rozumiany jest jako coś wspólnotowego. Ks. prof. Czesław S. Bartnik nazywa tę rzeczywistość „,bierzmowaniem Kościoła”. Pisze, że

Kościół Jezusa Chrystusa był w swoich początkach bierzmowany jako całość, bez względu na to, jak to ujmiemy: jako zesłanie Ducha Świętego w Pięćdziesiątnicę (Łukasz), jako nadanie pieczęci Chrystusa uwielbionego (Paweł) czy jako tchnienie weń Ducha (Jan). Aktów takich było w dziejach zbawienia zapewne wiele, na podobieństwo innych aktów powstawania Kościoła, i sięgały zapewne pierwszych chwil historii Jezusa Chrystusa, ale osiągnęły swój szczyt i punkt istotny po wywyższeniu Jezusa Chrystusa. Wtedy to musiał nastąpić podstawowy akt namaszczenia ca-

${ }^{1}$ Por. A. SKowroneK, Wokót eklezjalnego aspektu chrztu i bierzmowania, „Ateneum Kapłańskie", 58(1966), t. 69, s. 1-9; A. SKowroneK, Sakrament bierzmowania; wprowadzenie teologiczne, „Materiały Problemowe”, 15(1986), s. 40-43.

2 Por. R. Sarah, Duch Święty w Kościele, w: J. Bartoszek, R. Chromy, K. Piechaczek (red.), Program duszpasterski na rok 2018/2019. W mocy Bożego Ducha, Katowice 2018, s. 147-160. 
łego Kościoła Duchem Świętym. I odtąd Kościół zaczął żyć z tego bierzmowania. Bierzmowanie to stało się bazą bierzmowania indywidualnego i rytualnego³.

To, co dotyczyło Kościoła powszechnego w jego początkach, odnosi się w pewnym znaczeniu do Kościołów lokalnych, mimo że nie można mówić, iż Kościoły te są identyczne. Wiemy, że

kwestia relacji między Kościołem powszechnym a Kościołami lokalnymi stała się szczególnie żywa po artykule Waltera Kaspera, w którym skrytykował on ten fragment Listu Kongregacji Nauki Wiary na temat Kościoła jako communio z 1992 r., w którym podkreślone zostało ontologiczne i czasowe pierwszeństwo Kościoła powszechnego wobec Kościoła lokalnego .

Kard. Walter Kasper stwierdził, że list, podpisany przez ówczesnego prefekta Kongregacji Nauki Wiary, kard. Josepha Ratzingera, jest jednym z etapów powrotu do centralizmu rzymskiego i odcięcia się od eklezjologii komunii Soboru Watykańskiego II. W odpowiedzi kard. Joseph Ratzinger podkreślił, że konieczny jest powrót do pierwotnego zamiaru ojców Soboru, którzy nie chcieli mówić o Kościele dla samego Kościoła, lecz stawiali na pierwszym miejscu Boga. Dodał ponadto, że po Soborze Watykańskim II doszło do wielu wypaczeń w rozumieniu zarówno pojęcia ludu Bożego, najbardziej nośnego w okresie posoborowym, jak i pojęcia communio $^{5}$.

Dla wywodu o teologiczno-eklezjalnym aspekcie bierzmowania istotny jest fakt, że, jak podkreślał kard. Ratzinger, „ontologiczna uprzedniość Kościoła uniwersalnego [...] w stosunku do konkretnego empirycznego urzeczywistnienia w poszczególnych Kościołach lokalnych wydaje się tak ewidentna, że trudno zrozumieć podnoszone przeciw niej sprzeciwy”. Kardynał krytykuje także tezę Kaspera, że pierwotna gmina jerozolimska była jednocześnie Kościołem uniwersalnym i Kościołem lokalnym. Ratzinger podkreśla, że z relacji św. Łukasza

3 Cz.S. Bartnik, Bierzmowanie Kościoła, „Collectanea Theologica”, 48(1978), z. 3, s. 27.

4 J. Bujak, Pierwszeństwo Kościoła powszechnego wobec Kościołów lokalnych, „Collectanea Theologica", 76(2006), nr 1, s. 39-55.

${ }^{5}$ Por. Nadzwyczajny Synod Biskupów, Relacja końcowa, „L’Osservatore Romano”, Dodatek do nr 10-11-12(1985), s. 1, 5, gdzie znajdujemy słowa świadczące o pragnieniu unikania wszelkiej jednostronności w pojmowaniu misterium Kościoła. Chodziło o próby zastępowania jednostronnej, czysto hierarchicznej wizji Kościoła koncepcją socjologiczną, a więc wskazywano na konieczność odejścia od próby ideologizacji modelu Kościoła pojętego jako lud Boży oraz przypominano, że Kościół to przede wszystkim misterium, które w pełni potwierdza, że communio to przede wszystkim spotkanie człowieka z Bogiem. 
o pierwszej gminie chrześcijańskiej wynika, iż ,absolutnym początkiem nie jest pierwsza gmina jerozolimska, lecz fakt, że w Dwunastu stary Izrael, który jest jeden jedyny, staje się nowym Izraelem i że ten jeden jedyny Izrael Boga, dzięki cudowi języków, ukazuje się - zanim jeszcze doszło do powstania jerozolimskiego Kościoła lokalnego - jako jedność, która obejmuje wszelki czas i wszelką przestrzeń"6.

Najważniejszym tekstem dotyczącym relacji między Kościołem powszechnym a Kościołami lokalnymi jest punkt 23 Konstytucji dogmatycznej o Kościele, gdzie czytamy, że poszczególni „biskupi są widzialnym źródłem i fundamentem jedności w Kościołach partykularnych, uformowanych na wzór Kościoła powszechnego, w których istnieje i z których się składa (in quibus et ex quibus) jeden i jedyny Kościół katolicki"7. Warto dodać, że sprawowanie najwyższej władzy Biskupa Rzymu nie znosi, lecz potwierdza, umacnia i broni władzę zwyczajną, własną i bezpośrednią biskupa w jego Kościele partykularnym ${ }^{8}$.

Według Katechizmu Kościoła Katolickiego ważkim skutkiem bierzmowania jest specjalne wylanie Ducha Świętego jak to, które zostało udzielone w dniu Pięćdziesiątnicy (KKK 1302). Nawiązując do zesłania Ducha Świętego na zgromadzonych w Wieczerniku, należy podkreślić, że właśnie wówczas pierwszego bierzmowania Kościoła dostąpili Apostołowie, którzy wraz z Maryją oczekiwali na wydarzenie Pięćdziesiątnicy. Warto dodać, że św. Łukasz, który przyjmuje koncepcję licznych, powtarzających się zesłań Ducha Świętego na Chrystusa9 i na Kościół ${ }^{10}$, rozszerza bierzmowanie na kolejne Kościoły, począwszy od Jerozolimy. Już w Jerozolimie trzeba było specjalnej interwencji Ducha dla przeciwstawienia się dominującemu judaizmowi, który jeszcze za życia Apostołów chciał, aby chrze-

${ }^{6}$ J. Ratzinger, Pielgrzymująca wspólnota wiary. Kościót jako komunia, Kraków 2003, s. 6.

7 Por. M. Semerano, Le Chiese particolari formate a immagine della Chiesa universale (LG23). Analisi e interpretazioni di una formula, w: N. Ciola (red.), Servire Ecclesiae. Miscellanea in onore di mons. Pino Scabini, Bologna 1998, s. 303-348 (zwł. 307-330). Semerano zauważa, że podczas prac nad schematem konstytucji o Kościele problem relacji między Kościołem powszechnym a Kościołami lokalnymi przeszedł prawie niezauważony, ponieważ jego autorom chodziło głównie o wykazanie, że wzajemne relacje biskupów z ich Kościołami i z Kościołem powszechnym ukazują ich kolegialną jedność.

${ }^{8}$ Por. JAN Pawel II, Posynodalna adhortacja apostolska Pastores gregis, Rzym 2003, nr 56.

9 Należy przyznać, że swoistą Pięćdziesiątnicą był chrzest Chrystusa w Jordanie, którego skutkiem było ustanowienie Go pierwszym i jedynym w swoim rodzaju apostołem Boga - Ojca Przedwiecznego. Por. J. Kudasiewiecz, Chrzest Chrystusa, „Ateneum Kapłańskie”, 57(1965), t. 67, s. 163; L. Balter, Duch, który woła, w: L. Balter (red.), Powołanie czlowieka, t. IV, PoznańWarszawa 1980, s. 35-47.

${ }^{10}$ Św. Łukasz zwraca uwagę na Kościół, który jest niejako „Chrystusem społecznym”. Por. A. SKowroneK, Z teologii bierzmowania, „Studia Theologica Varsaviensia”, 13(1975), nr 1, s. 25-42; Cz.S. BartniK, Bierzmowanie Kościoła, „Collectanea Theologica”, 48(1978), z. 3, s. 19-30. 
ścijaństwo bezwzględnie przystosowało się do wszystkich zasad judaizmu. W ten sposób rozpoczęła się cała seria namaszczeń Jezusa Chrystusa jako głowy Kościoła w celu uobecniania Kościoła powszechnego w Kościołach lokalnych oraz budowania i głoszenia królestwa Bożego na ziemi (por. Łk 16,16).

Bierzmowanie pozwala więc utworzyć specjalny model powstawania i rozwoju nowych Kościołów. W oparciu o zasadę inegzystencji (inexistentio) tego, co totalne, w tym, co pojedyncze, można mówić o bierzmowaniu jakiejś odrębnej wspólnoty Kościoła, np. o bierzmowaniu Kościoła lokalnego. Każdy nowy etap urzeczywistniania królestwa Bożego w konkretnej wspólnocie Kościoła lokalnego ma swoje źródło i początek w tchnieniu Ducha, a więc w bierzmowaniu tego Kościoła, który - na mocy namaszczenia Duchem Świętym - promieniuje na środowiska, które w mocy Ducha stają się kościołotwórcze. Jak zesłanie Ducha Świętego było inauguracją życia i działania Kościoła oraz budulcem jego jedności, tak obecnie biskupi, udzielając daru tego samego Ducha, jednoczą wiernych zgromadzonych w parafii z diecezją, a przez nią - z Kościołem powszechnym (por. KK 11; DV 25; KKK 1303, 1313) ${ }^{11}$, umacniając tym samym inne wspólnoty eklezjalne, zwłaszcza w momencie zagrożeń wiary przez wrogie otoczenie, na które również oddziałują w misji nowej ewangelizacji. Tak zresztą było już od czasów masowych nawróceń na chrześcijaństwo w Samarii, opisywanych w Dziejach Apostolskich (por. Dz 8,14-18).

Można śmiało mówić charyzmacie męczeństwa, czyli darach Ducha Świętego wśród prześladowań (Dz 4,31-32). Jest to bez wątpienia aplikacja daru Pięćdziesiątnicy, nazywanej uroczystością Zielonych Świąt, a zarazem kultywowanej jako zwieńczenie świąt paschalnych ${ }^{12}$. Nie ulega wątpliwości, że analogiczne wylania Ducha Świętego występują wszędzie tam, gdzie Kościół jest prześladowany, zagrożony błędem i odstępstwem od Prawdy, a zwłaszcza tam, gdzie - jak w przypadku krajów misyjnych - dopiero zapuszcza swoje korzenie. Tak było również w przypadku Polski. Mocno podkreślił to św. Jan Paweł II podczas pierwszej pielgrzymki do Ojczyzny, gdy - celebrując dziewięćsetsetną rocznicę męczeńskiej śmierci św. Stanisława Biskupa - 10 czerwca 1979 roku na Błoniach krakowskich dokonał wielkiego „bierzmowania Narodu”, zmagającego się z propagowaną ateizacją. Powołując się właśnie na ten sakrament, pobłogosławił swoją

${ }^{11}$ Por. W. Śmigiel, Teologia sakramentu bierzmowania, w: J. BARtoszeK, R. Chromy, K. Piechaczka (red.), Jesteśmy napetnieni Duchem Świętym, Katowice 2017, s. 73-74.

${ }_{12}$ Por. R. Rak, Duch Święty jako Dar i Jego dary, w: A.L. Szafrański (red.), Jan Pawet II, Dominum et Vivificantem. Tekst $i$ komentarz, Lublin 1994, s. 137-140; Cz. Krakowiak, Z problematyki teologicznej sakramentu bierzmowania, „Roczniki Teologiczno-Kanoniczne”, 21(1974), z. 4, s. 38-39. 
Ojczyznę, przekazując rodakom moc Ducha Świętego. W ten sposób papież Polak podkreślił, że przyjęcie darów Ducha owocuje wiernością, ufnością i „wolnością ducha”. W wygłoszonej wówczas homilii św. Jan Paweł II powiedział:

Pozwólcie przeto, że tak jak zawsze przy bierzmowaniu Biskup, i ja dzisiaj dokonam owego apostolskiego włożenia rąk na wszystkich tu zgromadzonych, na wszystkich moich rodaków. W tym włożeniu rąk wyraża się przejęcie i przekazanie Ducha Świętego, którego apostołowie otrzymali od samego Chrystusa, kiedy po zmartwychwstaniu przyszedł do nich „drzwiami zamkniętymi” (por. J 20,19) i rzekł: „Weźmijcie Ducha Świętego" (J 20,22). Tego Ducha: Ducha zbawienia, odkupienia, nawrócenia i świętości, Ducha prawdy, Ducha miłości i Ducha męstwa - odziedziczonego jako żywą moc po apostołach - przekazywały po tyle razy biskupie dłonie całym pokoleniom na ziemi polskiej. Tego Ducha pragnę wam dzisiaj przekazać, tak jak przekazywał Go swoim współczesnym biskup rodem ze Szczepanowa. Pragnę wam dziś przekazać tego Ducha, ogarniając sercem z najgłębszą pokorą to wielkie „bierzmowanie dziejów”, które przeżywacie. Więc mówię za Chrystusem samym: „Weźmijcie Ducha Świętego!” (J 20,22). I mówię za Apostołem: „Ducha nie gaście!” (1 Tes 5,19). I mówię za Apostołem: „Ducha Świętego nie zasmucajcie!” (por. Ef 4,30) ${ }^{13}$.

Jak wynika z przytoczonego fragmentu homilii papieskiej, bierzmowanie jest manifestacją tajemnicy Trójcy Świętej i Kościoła, w którym Bóg udziela wiernym swojego Ducha. Kościół zaś, na mocy misterium bierzmowania, jest na ziemi znakiem zmartwychwstania Chrystusa i wiekuistej misji Ducha Świętego, która staje się nieustannie misją Kościoła w dziejach ludzi i narodów. Nie trzeba dowodzić, że Pascha bez tajemnicy zstąpienia Ducha Świętego pozostałaby pozbawiona swojego wewnętrznego dynamizmu, Pięćdziesiątnica bez Paschy natomiast utraciłaby swój najgłębszy sens. Dopiero dzięki uznaniu bierzmowania jako uobecniającej się sakramentalnie Pięćdziesiątnicy Kościół nieustannie partycypuje w paschalnym misterium Chrystusa: misterium męki, śmierci, zmartwychwstania, wniebowstąpienia i zesłania Ducha Świętego. Pięćdziesiątnica celebrowana podczas udzielania sakramentu bierzmowania stanowi więc istotny element włączenia się w misterium uwielbienia Chrystusa zmartwychwstałego oraz oczekiwania na ostateczne urzeczywistnienie Jego królestwa, które w Chrystusie zasiadającym po prawicy Ojca już stało się rzeczywistością.

Dzięki skutkom bierzmowania Kościoła jako całości moc Ducha Świętego, który działa mimo niepełnego, a czasem nawet przeciwnego misji Chrystusa za-

${ }^{13}$ Pielgrzymka Jana Pawła II do Polski. Przemówienia. Dokumentacja, Poznań-Warszawa 1979, s. 209. 
angażowania niektórych członków Kościoła, królestwo Boże zdąża ponad wszelką wątpliwość do swego ostatecznego spełnienia. Kościół jako całość, nawet przy niewierności znacznej liczby jego wyznawców, a także wzrastającej liczby apostatów, zawsze zwycięża wszelkie opory i burze dziejowe zgodnie ze słowami Jezusa: „Bramy piekielne go nie przemogą” (Mt 16,18).

\section{UCZESTNICTWO BIERZMOWANYCH W APOSTOLSKICH ZADANIACH KOŚCIOŁA}

Posoborowe ujęcie Kościoła jako communio każe rozważać go jako dzieło Ducha Świętego, czyli urzeczywistnianie wspólnoty braci i sióstr w Chrystusie dzięki tej mocy, jaką daje zjednoczenie człowieka z trójcą Osób Bożych ${ }^{14}$. Zasada communio, inaczej niż potrydencka koncepcja Kościoła, pozwala na opracowanie integralnej koncepcji jego budowania we wspólnocie lokalnej, na podejmowanie działań planowych i skutecznych. Chodzi tu o dowartościowanie Kościoła jako wspólnoty służb i charyzmatów, w którym urząd i charyzmat przenikają się dla urzeczywistniana jedności Kościoła ${ }^{15}$. Myśl tę potwierdza nauczanie Benedykta XVI/Josepha Ratzingera, który już jako profesor i kardynał w pełni podzielał zdanie, iż

w niektórych ujęciach eklezjologii rozumienie Kościoła jako misterium komunii okazuje się niewystarczające, ponieważ przede wszystkim nie uwzględniają one związku między pojęciem komunii, a pojęciami ludu Bożego i Ciała Chrystusa oraz niedostatecznie uwypuklają relację zachodzącą między Kościołem jako komunią i Kościołem jako sakramentem ${ }^{16}$.

Z personalistycznej koncepcji sakramentu bierzmowania Kościoła ${ }^{17}$ wynika, że bierzmowanie indywidualne każdego wyznawcy Chrystusa, które słusznie definiujemy jako osobową Pięćdziesiątnicę, jest kontynuacją i niejako uobecnieniem tego, co dokonało się w Jezusie z Nazaretu i wciąż dokonuje się w Jego

\footnotetext{
${ }^{14}$ Por. M. JAGodzIŃski, Communio dzięki komunikacji. Teologiczny wymiar teorii komunikatywnego działania w eklezjologii Medarda Kehla SJ, Radom 2002; H. Szmulewicz, Bóg Trójjedyny źródtem jedności sakramentów wtajemniczenia, „Pedagogika Katolicka”, 2(2008), s. 238-255.

${ }^{15}$ Por. L. Balter, Kapłaństwo Ludu Bożego, Warszawa 1982, s. 61-80.

${ }^{16}$ J. Szymiк, Teologia na początek wieku, Katowice - Ząbki 2001, s. 226. Por. J. Ratzinger, Eklezjologia Soboru Watykańskiego II, w: L. Balter, K. Czulak, P. GóralczyK (red.), J. Ratzinger, Kościót-ekumenizm - polityka, Kolekcja Communio 5, Poznań 1990, s. 13-27.

${ }^{17}$ Cz. Bartnik, Bierzmowanie Kościoła, „Collectanea Theologica”, 48(1978), z. 3, s. 27. Por. Cz. BARTniK, Sakrament bierzmowania, „Roczniki Teologiczno-Kanoniczne”, 36(1989), z. 2, s. 45-53.
} 
Kościele. Sakrament bierzmowania zobowiązuje każdego z wiernych do odnalezienia swego miejsca we wspólnocie kościelnej, określanej od początku jako dom (chodzi tu jednocześnie o Kościół lokalny, parafialny i domowy/rodzinny - ecclesia domestica: Rz 16,5.23; 1 Kor 16,19; Kol 4,15; Flm 2) ${ }^{18}$ oraz „,do pełniejszego udziału poprzez tę wspólnotę w mesjańskich funkcjach Jezusa" ${ }^{\prime 19}$.

Należy zauważyć, że z perspektywy personalistycznej teologowie podkreślają związek bierzmowania z chrztem, jeśli chodzi o włączenie w Kościół, odnalezienie swego właściwego miejsca w Kościele oraz przyjęcie pełnej odpowiedzialności za losy Kościoła ${ }^{20}$. Wynika to z oczywistego faktu, że chrzest stanowi inicjację w stosunku do eschatologicznej wspólnoty zbawionych, przy czym ,inicjacja dokonująca się w chrzcie ma charakter bardziej chrystologiczny (włączenie w tajemnicę paschalną Jezusa Chrystusa, wpółumieranie i współzmartwychwstanie z Nim), zaś inicjacja w sakramencie bierzmowania ma charakter zasadniczo pneumatologiczno-eklezjalny (Kościół jako dzieło Ducha Świętego)”21.

$\mathrm{Z}$ całą pewnością należy stwierdzić, że największym i właściwym darem sakramentu bierzmowania jest sam Duch Święty, dzięki któremu udoskonala się więź bierzmowanego z Kościołem jako wspólnotą ludu Bożego ${ }^{22}$. Na skutek bierzmowania każdy chrześcijanin ma prawo odnieść do siebie słowa proroka: „Duch Pański nade mną, dlatego mnie namaścił i posłał mnie, abym głosił radosną nowinę ubogim” (Łk 4,18). Do tego samego zachęca Apostoł Paweł: „Tak i wy, skoro ubiegacie się o dary Ducha, starajcie się obfitować w te, które służą ku zbudowaniu Kościoła” (1 Kor 14,12). „W tym ciągłym wzrastaniu może mieć miejsce, i to wielokrotnie, nowe «wylanie Ducha»"23. To wylanie Ducha będzie

${ }^{18}$ Por. M. Kluz, Dynamizm sakramentów chrztu i bierzmowani w stużbie budowania Kościoła jako domu, „Liturgia Sacra”, 18(2012), nr 1, s. 71-83. Nawiązując do treści artykułu, warto przypomnieć, że św. Jan Paweł II w adhortacji apostolskiej Novo millennio ineunte napisał: „Czynić Kościół domem i szkołą komunii - oto wielkie wyzwanie, jakie czeka nas w rozpoczynającym się tysiącleciu, jeśli chcemy pozostać wierni Bożemu zamysłowi, a jednocześnie odpowiedzieć na najgłębsze oczekiwania świata" (NMI 43).

${ }^{19}$ Sobór Watykański II, Dekret o apostolstwie świeckich, nr 3; D. KwIATKowsKi, Bierzmowanie sakramentem umacniajacym żywa wiarę, która prowadzi do świadectwa i apostolstwa, w: https:// opoka.org.pl/biblioteka/M/MS/dk_bierzmowanie.html (dostęp: 12.05.2019). Por. J. BuXAKowsIKI, Teologia bierzmowania, „Ateneum Kapłańskie”, 58(1966), t. 69, s. 9-21.

${ }^{20}$ Por. J. Królıkowski, Umocnienie $i$ dopetnienie chrztu. Z teologii bierzmowania jako sakramentu wtajemniczenia chrześcijańskiego, w: J. Stala (red.), Dzisiejszy bierzmowany. Problemy $i$ wyzwania, Kielce 2005, s. 44-45.

${ }^{21}$ D.Z. SкRoK, Tendencje wspótczesnej teologii sakramentu bierzmowania, „Studia Theologica Varsaviensia", 42(2004), nr 2, s. 63. Por. C. KRAKowiaK, Z problematyki teologicznej sakramentu bierzmowania, „Roczniki Teologiczno-Kanoniczne”, 21(1974), z. 6, s. 38-45.

${ }^{22}$ Por. Cz.S. BARTniK, Istota więzi eklezjalnej, „Studia Płockie”, 23(1995), s. 11-17.

${ }^{23}$ P.-T. СамеLот, Bierzmowanie a wylanie Ducha, „Communio”, 12(1992), z. 2, s. 88. 
służyć ,ciągłemu wzrastaniu do głębszej wiary, silniejszej nadziei i doskonalszej miłości ucznia Chrystusa, «ku głębszemu poznaniu tajemnicy Boga - [to jest] Chrystusa» (1 Kor 2,2)"24.

Pochylając się nad słowami Konstytucji dogmatycznej o Kościele Lumen gentium, które brzmią: „Przez sakrament bierzmowania (wierni) jeszcze ściślej wiążą się z Kościołem” (KK 11), należy przyznać, że - zespolony ściśle z Panem - bierzmowany wkracza faktycznie, w sposób pełny i dojrzały, w życie Kościoła. Wymaga się zatem od niego pełnego uczestnictwa w misji tegoż Kościoła. Duch Święty jako osoba-dar, ubogacając ludzi różnorakimi darami, sprawia, że stają się oni apostołami, prorokami, nauczycielami; przekazuje im moc uzdrawiania, obecności, mówienia językami, itd. ${ }^{25}$ Dzięki tym darom (charyzmatom) wypełniają oni różne posługi, z tym, że wszystkie mają na celu wzmocnienie i większe zespolenie Ciała Chrystusowego, w którym każdy członek pełni właściwą sobie funkcję (por. 1 Kor 12,27-28). Dlatego św. Paweł napomina wiernych, aby, ,prorokując”, budowli Kościół, oraz wyraża życzenie, aby ci, którzy mówią językami, starali się o wyjaśnianie swych słów dla budowania Kościoła (zgromadzenia ludu Bożego). Ten, kto prorokuje lub wyjaśnia swój dar, otrzymał łaskę mówienia do ludzi celem ich budowania, zachęcania i umacniania, przez co kształtuje Kościół zgodnie z wolą Bożą i nadaje mu większą spoistość (por. 1 Kor 14,2-5). Wszystko to dzieje się w Ciele Chrystusa, który uświęca ,świętych” i pozwala swą mocą zespolić wszystko w sobie jako głowie. Chodzi bowiem o to,

abyśmy już nie byli dziećmi, którymi miotają fale i porusza każdy powiew nauki, na skutek oszustwa ze strony ludzi i przebiegłości w sprowadzaniu na manowce fałszu [oraz] żyjąc prawdziwie w miłości [sprawiali], by wszystko rosło ku Temu, który jest Głową - ku Chrystusowi. Z Niego całe Ciało - zespalane i utrzymywane w łączności dzięki całej więzi umacniającej każdy z członków stosownie do jego miary - przyczynia sobie wzrostu dla budowania siebie w miłości (Ef 4,14-16).

Jest to możliwe, gdyż bierzmowanie udziela mocy uczestniczenia w prawdziwie kapłańskim, prorockim i królewskim zaangażowaniu w życie i posłannictwo Kościoła (por. KK 10).

Z powyższymi słowami współbrzmią obowiązki wymienione przez program duszpasterski dla Kościoła w Polsce na rok 2017/2018, zgodnie z którym „na szczególną uwagę zasługuje troska o odnowienie w sobie Bożego synostwa,

\footnotetext{
${ }^{24}$ S. KUnKa, Sakrament bierzmowania a wylanie Ducha, „Teologia i człowiek”, 38(2017), s. 48.

${ }^{25}$ Por. P. Schoonenberg, Duch Boży w historii zbawienia, „Communio”, 8(1988), nr 1, s. 76-88.
} 
odkrywanie własnej tożsamości chrześcijańskiej, zrozumienie wagi osobistego wyboru Chrystusa, ściślejsze zjednoczenie się z Nim oraz odkrywanie parafii jako wspólnoty rozwoju i dojrzewania wiary”26. Świadectwo takiej wspólnoty staje się możliwe dzięki przyjęciu zaproszenia do pełniejszego i bliższego naśladowania Chrystusa, posłanego przez Ojca, aby jako „Pierworodny między wielu braćmi” (Rz 8,29) ustanowił przez dar swego Ducha nową wspólnotę braterską, starającą się z całej mocy żyć Kościołem, nawiązując w stylu swego życia do braterskiej wspólnoty jerozolimskiej. W świetle wymogów chrześcijańskiej doskonałości wszystkie wspólnoty eklezjalne winny bowiem dążyć do jedności, porównywalnej do ,ikony” Trójcy Świętej, wprowadzając głęboką komunię między wszystkimi ochrzczonymi i Bogiem Ojcem, przez Chrystusa, w Duchu Świętym ${ }^{27}$.

Odnośnie do relacji między duchownymi i świeckimi w wypełnianiu specyficznych zadań Kościoła przedmiotem refleksji teologicznej należałoby też uczynić problem niewielkiego włączenia w Kościół na początku trzeciego tysiąclecia chrześcijaństwa, co może skutkować zaledwie szczątkowym zaangażowaniem świeckich wyznawców Chrystusa w życie wspólnot eklezjalnych. Dla przezwyciężenia tego niedosytu pomocna może być refleksja sformułowana przez Adrienne von Speyr, która znamiennie wyraziła specyfikę łaski bierzmowania. Autorka ta pisze:

Łaska bierzmowania polega na eklezjalnym przekazaniu Ducha Świętego eklezjalnego, czyli na umocnieniu wierzącego w jego zmyśle kościelnym i w przeświadczeniu, że Kościół jest nie tylko instytucją, ale także życiem [...] [Bierzmowanie] zespala z Kościołem, ale właśnie dlatego, że czyni chrześcijan ludźmi dojrzałymi. Być zaś człowiekiem dojrzałym to stawać się zdolnym do autonomicznego osądzania w łonie Kościoła oraz patrzenia na wszystko oczyma Kościoła ${ }^{28}$.

W przytoczonych słowach dochodzi do głosu myśl św. Tomasza z Akwinu, który wyraża się następująco: „Podobnie jak ochrzczony otrzymuje duchową moc wyznawania wiary, przystępując zwłaszcza do innych sakramentów, tak bierzmowany otrzymuje moc publicznego wyznawania słowami wiary chrześcijańskiej jakby w formie zobowiązania ${ }^{29}$.

${ }^{26}$ Wprowadzenie redakcji, w: A. Skreczko i in (red.), Jesteśmy napetnieni Duchem Świętym, „Studia Teologiczne, Białystok - Drohiczyn - Łomża”, 35(2017), s. 5-6. Por. A. ŻĄDŁo, O bierzmowaniu z inspiracji Programu duszpasterskiego Kościoła w Polsce na rok 2017/2018, „Liturgia Sacra”, 24(2018), nr 1, s. 145-172.

${ }^{27}$ Por. M. Figura, Specyfika wspólnoty chrześcijańskiej, „Communio”, 23(2003), nr 4, s. 3-20.

${ }^{28}$ A. Von SPeyr, Mistica oggettiva, Milano 1975, s. 166.

${ }^{29}$ Tomasz z Akwinu, Suma teologiczna, III, 72, 5. 
Jak wynika z nowego Ordo confirmationis ${ }^{30}$, czyli Księgi obrzędów sakramentu bierzmowania, sakrament ten, przez swój charakter, upodabnia człowieka do Chrystusa, dzięki niemu bierzmowany potwierdza i umacnia swój związek z Chrystusem i Kościołem, włączając się jak najpełniej do przekazywania życia Chrystusowego innym ludziom i do kontynuowania Jego misji w świecie. Innymi słowy, charakter sakramentalny bierzmowania polega na „pewnym uzdolnieniu do budowania Kościoła jako Mistycznego Ciała Jezusa, pogłębienia z nim więzów i rozwijania Kościoła. Jest to po prostu Chrystusowa pieczęć kościelności”31. Chodzi tu więc o uzdolnienie do podjęcia - na mocy charakteru sakramentalnego bierzmowania - apostolskich zadań Kościoła przez wiernych świeckich, którzy są prawdziwymi apostołami Jezusa Chrystusa z faktu samej przynależności do Kościoła, a nie z mandatu hierarchii. Sobór Watykański II zachęca duchownych, aby tę - płynącą z charakteru bierzmowania - godność i odpowiedzialność świeckich w Kościele w pełni uznali i wykorzystali w duszpasterstwie. W Konstytucji dogmatycznej o Kościele do duchownych odnoszą się słowa: „Mają korzystać z ich [świeckich] roztropnej rady, powierzać im z ufnością zadania w służbie Kościoła i pozostawiać swobodę oraz pole działania, owszem, dodawać im ducha, aby także z własnej inicjatywy przystępowali do pracy” (KK 37).

Trudno jest jednak uniknąć wrażenia, że zarówno wskazania Soboru, jak i zachęty płynące z nauczania teologów odnośnie do zadań eklezjalnych świeckich wyznawców Chrystusa pozostają ciągle raczej w sferze teorii niż praktycznej realizacji. Można, niestety nie bez podstaw, powiedzieć, że w Kościele nadal wszystko „robią” księża ${ }^{32}$. Warto w tym miejscu zwrócić uwagę na wynikające z takiej sytuacji trudności i niedociągnięcia. Zalicza się do nich ${ }^{33}$ :

(1) pozorowanie współpracy, która polega na tworzeniu w parafii wspólnot i ruchów eklezjalnych ad hoc, doraźnie i bez uprzedniego przygotowania;

(2) następne niedociągnięcie ma miejsce wówczas, gdy duszpasterz bez doświadczenia życia wspólnotowego próbuje tworzyć grupę w parafii, nie w sposób organiczny, ale formalnie i bez należytego rozeznania możliwości zespołu ludzi, który najczęściej zawodzi;

\footnotetext{
${ }^{30}$ Por. Cz. Krakowiak, Problemy teologiczne i pastoralne podczas prac nad „, Ordo Confirmationis” 1971, „Seminare. Poszukiwania naukowe”, 35(2014), nr 3, s. 57-73.

${ }^{31}$ A.L. SZAFRAŃSKI, Z badań nad charakterem sakramentalnym bierzmowania, „Roczniki Teologiczno-Kanoniczne", 2(1955), s. 29.

${ }^{32}$ Por. R. Kostecki, Bierzmowanie - sakrament niewykorzystany, „Ateneum Kapłańskie”, 58(1966), t. 69, s. 21-28; A. ZUBERBIER, Współodpowiedzialność świeckich w zbawczym posłannictwie Kościoła, „Ateneum Kapłańskie”, 82(1990), t. 114, s. 388-393.

${ }^{33}$ Cyt. za: M. KowalczyK, Parafia wspólnota wspólnot, w: I. Chєopkowska, W. Kazimieruk (red.), Chrzest w życiu i misji Kościoła (II), Siedlce 2007, s. 35-36.
} 
(3) rozczarowanie duszpasterza może prowadzić do uprzedzeń, a nawet traktowania wspólnot i ruchów odnowy jako grup sekciarskich. Z drugiej zaś strony właśnie niechęć kapłana może wywołać tendencje sekciarskie w grupach, które zostaną pozbawione dbającego o czystość doktryny katolickiej oka duszpasterza;

(4) trudności w budowaniu parafii jako wspólnoty wspólnot wynikają także $\mathrm{z}$ niedelikatności księdza w relacjach z wiernymi. Może to wszystko doprowadzić do zniechęcenia w angażowaniu się na rzecz Kościoła lub też traktowania go jako zwykłego urzędu, ze wszystkimi właściwymi mu wadami;

(5) w końcu nie służy budowie parafii zbyt ścisła współpraca na płaszczyźnie instytucjonalnej ze świeckimi przedstawicielami władzy, którzy zwykle działają z motywów pozareligijnych, wskutek czego autorytet Kościoła zostaje nadużyty dla celów koniunktury politycznej.

Przykładowo wyliczone niedociągnięcia, a nawet nadużycia, w niczym nie przysłaniają pozytywnych przykładów wzajemnej współpracy i współodpowiedzialności za Kościół, co można bez wysiłku odkryć w przedstawionych wyżej zasadach dotyczących eklezjologii komunii. Dla zmiany tej sytuacji konieczne jest uświadomienie sobie faktu, iż udział w Bożej naturze, na który wskazuje Paweł VI w tytule Konstytucji apostolskiej o bierzmowaniu, jest najgłębszym rdzeniem Kościoła, dzięki któremu przez Chrystusa w Duchu Świętym mamy przystęp do Ojca, aby w ten sposób stać się uczestnikami Bożej natury, a więc - odnosząc się do relacji osób Bożych - uczestnikami communio trynitarnej. Udział w Bożej naturze, uwzględniając pochodzenia i posłannictwa osób Bożych, nie może być uczestnictwem zorientowanym ku wyłącznemu dobru obdarzonych nim w sakramencie bierzmowania jednostek. Domaga się otwarcia i pełnego zaangażowania apostolskiego wobec tych, z którymi bierzmowany tworzy wspólnotę Kościoła - mistycznego Ciała Chrystusa, do którego włączeni zostali wszyscy wierni ${ }^{34}$. Wypełniając zobowiązanie do apostolstwa, bierzmowany postępuje na wzór Syna Bożego, aby w ten sposób przekazywać poniekąd innym łaskę życia, umierania, zmartwychwstawania i obdarowywania Duchem Świętym jako osobowym darem. W tym właśnie znaczeniu upodobnienie do Jezusa Chrystusa uzdalnia bierzmowanych do stawiania czoła wyzwaniom czasu i nie pozwala znużyć się żadnymi przeciwnościami, słabościami czy niepowodzeniami apostolskimi ${ }^{35}$.

\footnotetext{
${ }^{34}$ Por. SobóR WatykaŃSKi II, Dekret o apostolstwie świeckich „Apostolicam actuositatem”, nr 3. Zob. hasło Miejsce świeckich w Kościele, udziat świeckich w życiu Kościoła, Zintegrowana Baza Tekstów Papieskich, http://www.nauczaniejp2.p1/ (dostęp: 16.07.2019).

${ }^{35}$ Por. B. BrzuszeK, Zobowiazanie wiernych świeckich do apostolstwa, „Collectanea Theologica", 42(1972), z. 3, s. 57-66; E. Weron, Apostolstwo katolickie, Poznań 1987, s. 108-
} 
Jak już wspomnieliśmy, pierwotną i podstawową formą apostolstwa świeckich jest świadectwo życia chrześcijańskiego, które w sposób szczególny akcentuje Sobór Watykański II. Tego rodzaju apostolstwo ma w samym sobie siłę przyciągającą do wiary i do Boga ${ }^{36}$. Na pierwszym miejscu należy tu postawić posługę słowa, ,apostolstwo słowa, czyli jedna z form realizacji prorockiej funkcji Chrystusa, jest - gdy chodzi o świeckich - tylko przedłużeniem tego apostolstwa życia" ${ }^{37}$. Świadczy to dobitnie, że człowiek jako osoba wyraża się w słowie, które mieści w sobie świat realny i rekapituluje w sobie wszelką rzeczywistość - obecną i możliwą. Człowiek jako mikrokosmos jest też pewnym logosem świata i historii (Ef 1,10). Podejmując posługę słowa, bierzmowany powinien zgłębić prawdę, ,że celem poznawania i interpretacji Pisma Świętego jest budowanie Kościoła, a dzieje się to przez budowanie jedności z Jezusem Chrystusem"38.

Bez wątpienia najważniejszym miejscem proklamacji słowa Bożego jest liturgia, albowiem w zgromadzeniu liturgicznym jest ono czytane i przeżywane w sposób uroczysty, dzięki czemu dokonuje się przyjęcie go przez każdego uczestnika celebracji. „Słowo wychodzi z ust Boga, świadczy o nim Pismo, po czym powraca do Niego w postaci odpowiedzi modlącego się ludu"39. Bierzmowani spełniają posługę słowa Bożego urzędowo, jako lektorzy, jednak muszą być świadomi, że nie tylko urzędowe posługi, lecz także zwykłe, codzienne czy prawie codzienne kontakty bezpośrednie stwarzają wiele możliwości apostolstwa słowa i one przede wszystkim powinny być wykorzystane z przekonaniem, że „każde wypowiedziane słowo może być narzędziem przekazu słowa Bożego, każda rozmowa może być nośnikiem apostolstwa słowa i byłoby rzeczą niewłaściwą angażowanie się w upowszechnianie słowa Bożego przy pomocy środków społecznego przekazu, zaniedbując przekaz, jakim może być rozmowa" ${ }^{40}$.

109; M. Lena, Źródto życia apostolskiego, „Communio”, 8(1988), s. 144-177; S. NAGY, Świeccy w komunijnej wspólnocie Kościoła, „Ateneum Kapłańskie”, 82(1990), t. 114, s. 377-387.

${ }^{36}$ Por. DA 6; KK 11; DM 11, 58; L. BALTER, Kapłaństwo Ludu Bożego, Warszawa 1982, s. 181-208.

${ }^{37}$ M. KowalczyK, Eklezjalno-apostolski charakter bierzmowania, „Communio”, 12(1992), nr 2, s. 98.

${ }^{38}$ K. Bronk, Rozmowa z ks. prof. dr hab. Waldemarem Chrostowskim (Radio Watykańskie Sekcja Polska, 10.10.2008). Por. W. Chrostowski, Duszpasterstwo biblijne jako składnik nowej ewangelizacji, „Collectanea Theologica”, 72(2002), nr 3, s. 55-71.

${ }^{39}$ Instrumentum laboris na XII Zwyczajne Zgromadzenie Ogólne Synodu biskupów, Watykan 2008, nr 34.

${ }^{40}$ R. ForycKi, Z prakseologii apostolstwa stowa, w: M. KowalczyK (red.), Apostolat stowa Bożego, Biblioteka Instytutu Teologii Apostolstwa 9, Warszawa 2010, s. 263. 
Poza posługą słowa Bożego sakramenty inicjacji chrześcijańskiej, a zwłaszcza bierzmowanie, czynią ze świeckiego wyznawcy Chrystusa samodzielny podmiot w sprawowaniu liturgii, a nie tylko jej zwyczajnego odbiorcę. Bierzmowany powinien być w pełni świadomy, że podmiotem sprawowania liturgii jest cała wspólnota eklezjalna, a więc zarówno ogół wiernych, jak i każda osoba biorąca udział w liturgii posiada funkcję liturgiczną ${ }^{41}$, zgodnie z własną pozycją i własnym stanem w Kościele.

Do apostolskich zadań Kościoła podejmowanych przez bierzmowanych należą bez wątpienia dzieła miłosierdzia. Bierzmowani mają się starać, aby zawsze była zachowana naczelna zasada miłości bliźniego jako miłości miłosiernej. Wspaniały przykład pełnienia miłości miłosiernej w stosunku do ludzi dotkniętych niepełnosprawnością dają założone przez zmarłego 7 maja 2019 roku w Paryżu Jeana Vaniera dwa międzynarodowe ruchy o charakterze wspólnotowym: „L’Arche” oraz „Wiara i Światło” skupiające w swoich wspólnotach osoby zdrowe oraz niepełnosprawnych i ich rodziny, niemieszkające jednak pod wspólnym dachem, ale w jednej parafii, dzielnicy czy mieście. Ruchy te tworzą środowisko koncentrujące się wokół najsłabszych, wzywając zwłaszcza młodych, umocnionych sakramentalnym charakterem bierzmowania, do „większej troski o ludzi umysłowo ograniczonych, wskazując równocześnie na korzyści takiej troski dla ludzi zdrowych, którzy niosą pomoc ludziom niepełnosprawnym" ${ }^{42}$. Wspomniane tylko pobieżnie zaangażowania $\mathrm{w}$ apostolat miłosierdzia potwierdzają w całej pełni wskazania soborowego dekretu o apostolstwie świeckich: „Jakkolwiek wszelka działalność apostolska, winna się rodzić z miłości i z niej czerpać swe siły, to jednak niektóre dzieła z natury swej są zdatne do tego, by stać się żywym wyrazem samej miłości. Chrystus chciał, by były one znakami Jego mesjańskiego posłannictwa" (por. Mt 11,4-5) ${ }^{43}$.

\section{EWANGELIZACJA WSPÓŁCZESNEGO ŚWIATA PRZEZ BIERZMOWANYCH}

Na mocy posłannictwa osób Bożych komunia trynitarna wkracza w dzieje ludzi i uobecnia się w świecie. Sam duchowny nie jest w stanie reprezentować wspólnoty w świecie. Wierni świeccy, jako ochrzczeni i bierzmowani, prowadzeni przez

\footnotetext{
${ }^{41}$ Por. L. BaLter, Wspólnototwórcza rola liturgii, w: L. BALTER (red.), Człowiek we wspólnocie Kościoła, Warszawa 1979, s. 251-268.

${ }^{42}$ E. Weron, W kontekście VII Synodu Biskupów, „Collectanea Theologica”, 59(1989), z. 3, s. 93.

${ }^{43}$ DA 8.
} 
Ducha, są posyłani do świata, aby go ożywiać miłościąa ${ }^{44}$ Bierzmowany jest w swoim jedynym, osobowym bycie wezwany po imieniu (taki jest sens nowego imienia lub wezwania do pogłębionego rozumienia podczas przygotowań do bierzmowania imienia chrzcielnego $)^{45}$ do wnoszenia wkładu w odnowę oblicza ziemi.

Trzeba zrobić wszystko, żeby żaden talent, nawet najmniejszy, nie był zakopany i by nie pozostał bezużyteczny (por. Mt 25,24-27; 1 P 4,10). Tylko w ten sposób zbawcze dzieło Jezusa Chrystusa może wpływać na, dopełniającą się każdego dnia, historię zbawienia i osiągnąc swój skutek we wszystkich ludach i we wszystkich religiach świata, który dziś jest w ogromnej mierze albo jeszcze nie-chrześcijański, albo - co jeszcze bardziej bolesne - już post-chrześcijański ${ }^{46}$.

Według Benedykta XVI wiara oznacza zaangażowanie i publiczne świadectwo. Chrześcijanin, zwłaszcza po przyjęciu bierzmowania, pojmowanego powszechnie jako sakrament dojrzałości chrześcijańskiej, nigdy nie może myśleć, że wiara jest sprawą prywatną. Każdy powinien być wobec świata świadkiem zmartwychwstania i życia Pana Jezusa i znakiem Boga żywego. Wszyscy razem i każdy z osobna winni ożywiać świat owocami duchowymi (por. Ga 5,22) ${ }^{47}$. Zobowiązanie płynące z bierzmowania jest „decyzją na to, żeby być z Panem, aby z Nim żyć. To «bycie z Nim» wprowadza do zrozumienia powodów, dla których się wierzy"48.

${ }^{44}$ Por. FranciszeK, Błogosławieni mitosierni. Stowa do młodych, Kraków 2016, s. 158-159; B. Wolański, Nabożeństwo dziękczynne za sakrament bierzmowania: „Tak i Ja was posyłam”, w: J. BartoszeK i in. (red.), Program duszpasterski dla Kościoła w Polsce na rok 2018/2019. W mocy Ducha Bożego, Zeszyt liturgiczny, Katowice 2018, s. 65-69.

${ }^{45}$ Warto przypomnieć, że w Polsce dawny zwyczaj pozwalał na obranie przy bierzmowaniu nowego imienia. Obecnie wskazania liturgiczne oraz Kodeks Prawa Kanonicznego nic o tym nie wspominają, jedynie Instrukcja Episkopatu Polski z 1975 roku dotycząca sakramentu bierzmowania, powołując się na „starodawny zwyczaj polski”, zezwala na wybór nowego imienia. Dokumenty II Polskiego Synodu Plenarnego natomiast postanawiają, że „kandydat do bierzmowania powinien zachować imię chrzcielne. Jeśli jednak nie ma on świętego patrona z chrztu, może wybrać sobie imię świętego, który będzie dla mego wzorem dojrzałego życia chrześcijańskiego". Cyt za: ŚMigiel, Teologia sakramentu bierzmowania, s. 63. Por. M. FALK, Przygotowanie do sakramentu bierzmowania $w$ katechezie szkolnej $w$ oparciu o wybrane podręczniki do religii, w: J. Stala (red.), Dzisiejszy bierzmowany. Problemy i wyzwania, Kielce 2005, s. 202.

${ }^{46}$ KOWALCZYK, Eklezjalno-apostolski charakter bierzmowania, s. 99.

${ }^{47}$ Por. D. KwiATKowski, Bierzmowanie sakramentem umacniajacym żywa wiarę, która prowadzi do świadectwa i apostolstwa.

${ }^{48}$ Benedykt XVI, List apostolski w formie „motu proprio” Porta fidei ogłaszający Rok Wiary, Ząbki 2012, s. 13. 
Bierzmowanie uświadamia ponadto, że cały świat, jako miejsce realizowania zbawczego posłannictwa Chrystusa i Kościoła, będzie uczestniczył w przyszłej chwale zbawionych. Z posłannictwem Kościoła organicznie wiąże się więc społeczna troska bierzmowanych, którzy mają obowiązek uczynić wszystko, aby współcześni ludzie zrozumieli, że do definicji osoby ludzkiej należy Trójjedyny Bóg i że oddanie się Ojcu przez Chrystusa w Duchu Świętym, stanowiąc konstytutywny element pełnej osobowości człowieka, stawia go w samym centrum rzeczywistości świata. Kościół - jako społeczność widzialna - składa się z ludzi żyjących na tym świecie i jest powołany do ich uświęcania i zbawiania. Jest powołany do doskonalenia całego świata jako „zaczyn i niejako dusza społeczności ludzkiej, która ma się w Chrystusie odnowić i przemienić w rodzinę Bożą"49. Aby odpowiedzieć na to powołanie, bierzmowany jest zmuszony przywiązywać wielką wagę do urzeczywistnienia swego powołania w wymiarze świata i społeczeństwa, taką samą, jak w wymiarze osobowym i kościołotwórczym.

Kontynuując niejako powyższą myśl, Konstytucja duszpasterska o Kościele Gaudium et spes uczy, że

Kościół, idąc ku swemu własnemu zbawczemu celowi, nie tylko daje człowiekowi uczestnictwo w życiu Bożym, lecz także rozsiewa na całym świecie niejako odbite światło Boże, zwłaszcza przez to, że leczy i podnosi godność osoby ludzkiej, umacnia więź społeczeństwa ludzkiego oraz wlewa głębszy sens i znaczenie w powszednią aktywność ludzi. Dlatego też Kościół uważa, że przez poszczególnych swych członków i całą swoją społeczność może poważnie przyczynić się do tego, aby rodzina ludzka i jej historia stawały się bardziej ludzkie ${ }^{50}$.

Konieczne jest tu jednak ostrzeżenie Josepha kard. Ratzingera, który troszczył się, aby Kościół nie był postrzegany wyłącznie jako tzw. Kościół dla drugich, a więc niemyślący jedynie o własnej tożsamości i całkowicie zajęty dawaniem świadectwa i służeniem królestwu. W takim rozumieniu Kościół zostaje bowiem zepchnięty na margines, jest niedoceniany lub uważany za zwykły znak, zresztą niepozbawiony wieloznaczności ${ }^{51}$.

\footnotetext{
${ }^{49}$ Sobór Watykański II, Konstytucja duszpasterska o Kościele Gaudium et spes, nr 40. Por. KowALCZYK, Eklezjalno-apostolski charakter bierzmowania, s. 99-100.

${ }^{50} \mathrm{KDK} 40$.

${ }^{51}$ Por. Deklaracja Dominus Iesus, Watykan 2000, nr 19; J. RATzInger, Chrystus, wiara a wyzwanie kultur, „Communio”, 22(2002), nr 1, s. 88.
} 
Bierzmowani „mają obowiązek uczynić wszystko, co w ich mocy, aby każdego człowieka i każdą ludzką społeczność ostatecznie uczynić przedmiotem i podmiotem solidarnej miłości, a nie interesów, rozgrywek, machinacji społecznych, wtłaczaniem ludzi w starannie przemyślany system nagród i kar" ${ }^{\prime 52}$. Chodzi tu o integralny rozwój świata oparty na miłości Boga i bliźniego oraz przyczynianie się do polepszenia stosunków między jednostkami a społeczeństwem, czyli o budowanie tzw. cywilizacji miłości ${ }^{53}$, której przeciwieństwem stała się „cywilizacja śmierci”, z jej przerażającymi przejawami: aborcją, eutanazją, antykoncepcją, morderstwami, samobójstwami, homoseksualizmem, transseksualizmem, a zwłaszcza pedofilią. Wystarczy tu jedynie wspomnieć o tzw. kartach LGBT plus, które zaczynają obowiązywać, zwłaszcza w wielkomiejskich skupiskach ludzkich ${ }^{54}$.

Benedykt XVI, nawiązując do słów z szóstego rozdziału Ewangelii według św. Łukasza (Łk 6,27), które określił jako magna charta chrześcijańskiego niestosowania przemocy, zauważył, że nie polegają one na kapitulacji w obliczu zła - jak sugeruje błędna interpretacja słów „nadstaw drugi policzek” (por. Łk 6,29) - ale na odpowiadaniu na zło dobrem (por. Rz 12,17-21), co pozwala przerwać łańcuch niesprawiedliwości. Dla przyjmujących sakrament bierzmowania powinno być jasne, że

odrzucenie przemocy nie jest dla chrześcijan posunięciem czysto taktycznym, ale sposobem bycia osoby, postawą człowieka, który jest tak bardzo przekonany o miłości Bożej i o Jego mocy, że nie boi się walczyć ze złem jedynie bronią miłości i prawdy. Miłość nieprzyjaciół jest zaczątkiem „rewolucji chrześcijańskiej”, rewolucji, która nie bazuje na strategiach władzy ekonomicznej, politycznej czy medialnej. Jest to rewolucja miłości, miłości, która w ostatecznym rozrachunku nie opiera się na ludzkich zasobach, ale jest darem Boga, który się otrzymuje, gdy ufa się tylko i bez zastrzeżeń w Jego miłosierną dobroć. Oto nowość Ewangelii, która bez rozgłosu zmienia świat. Oto heroizm „małych”, którzy wierzą w miłość Bożą i ją szerzą nawet za cenę życia ${ }^{55}$

${ }^{52}$ M. KowalczyK, Teologia i apostolat laikatu, Biblioteka Centrum Teologii Apostolstwa „Pallottianum” w Ołtarzewie 9, Warszawa 2019, s. 173. Por. J. Pyrek, Czas dla miłości solidarnej, Kraków 1991, s. 21-45.

${ }^{53}$ S. UrbańsKi, Cywilizacja miłości w nauczaniu Jana Pawła II, w: J.M. DolęGA (red.), Solidarni z nauczaniem Jana Pawła II, Episteme 1, Olecko 1999, s. 31-45.

${ }^{54}$ Więcej: P. Nowak, Karta LGBT Plus: co to jest, gdzie obowiazuje?, https://www.radiozet.pl/Cogdzie-kiedy-jak/Karta-LGBT-Plus-co-to-jest-gdzie-obowiazuje (dostęp 29.07.2019).

${ }^{55}$ Benedykt XVI, Rozważanie przed modlitwa Aniol Pański (Watykan, 18.02.2007), „L'Osservatore Romano”, 26(2007), nr 4, s. 57. 
Chodzi tu ostatecznie o przedłużenie tego modelu jedności wewnętrznej, jaki bez trudu można odnaleźć w strukturze Kościoła, w którym lud Boży jest z natury otwarty na wzajemne przenikanie tego, co partykularne, z tym, co uniwersalne ${ }^{56}$.

Praca nad ukazanym przez Benedykta XVI odnawianiem społeczności ludzkiej jest własnym zadaniem ochrzczonych i bierzmowanych, którzy - będąc Kościołem są równocześnie cząstką świata, pozostając zaś osobami świeckimi, posiadają właściwą sobie autonomię, a wiec pracują z przysługującą sobie kompetencją i na własną odpowiedzialność ${ }^{57}$. Jednak odpowiedzialność ta wpisuje się w misję Kościoła, który powinien przede wszystkim chronić człowieka przed zniszczeniem samego siebie. Można tu mówić o czymś w rodzaju ekologii człowieka pojmowanej w sensie zgodnym z nauczaniem Kościoła ${ }^{58}$. Degradacja natury jest bowiem ściśle związana z kulturą i prawidłami wiary

kształtującymi współżycie ludzkie: kiedy „ekologia ludzka” jest szanowana w społeczeństwie, również ekologia środowiska czerpie z tego korzyści. Podobnie jak cnoty ludzkie są między sobą zespolone, tak że osłabienie jednej naraża także inne, tak też system ekologiczny opiera się na szacunku wobec projektu, dotyczącego zarówno zdrowego współżycia w społeczeństwie, jak i dobrej relacji z naturą ${ }^{59}$.

Wynika to z przekonania o „wzajemnym przenikaniu się państwa ziemskiego i niebiańskiego [...], aby rodzina ludzka i jej historia stawały się bardziej ludzkie" ${ }^{60}$.

$* * *$

Podsumowując, należy stwierdzić, że mocą otrzymanego w bierzmowaniu znamienia daru Ducha Świętego każdy człowiek ma moc ożywiania i uduchowiania - w Kościele i przez Kościół - wszystkiego, co go otacza, gdyż staje się zdolny do ożywiania całego uniwersum Duchem Bożym i Duchem Chrystusa. I tylko pod tym warunkiem możliwe jest - właściwe świeckim i płynące z ich specyficznego świeckiego charakteru - uświęcanie świa-

\footnotetext{
${ }^{56}$ Por. J. Ratzinger, Die Einheit der Nationen. Eine Vision der Kirchenväter, SalzburgMünchen 1971.

${ }^{57}$ Por. DA 7; KK 36; J. ZABŁocKI, Świeccy $w$ odnowie porządku doczesnego, „Ateneum Kapłańskie", 82(1990), t. 114, s. 397-406; E. HAMEL, Wiara a sprawiedliwość społeczna, „Communio”, 1(1981), nr 3, s. 39-51.

${ }^{58}$ Por. J. Dziedzic, Kościól a ekologia ludzka, „Polonia Sacra”, 23(2019), nr 1, s. 103-126.

${ }^{59}$ BenedyKt XVI, Encyklika Caritas in Veritate, Rzym 2009, nr 51

${ }^{60} \mathrm{KDK} 40$.
} 
ta (sanctificatio mundi) od wewnątrz, na kształt zaczynu ewangelicznego, dzięki czemu świeccy wcielają (incarnare) chrześcijaństwo w konkretny świat, prowadząc go do jego ostatecznego spełnienia w Bogu ${ }^{61}$. Odnosząc się do wskazań programu duszpasterskiego dla Kościoła w Polsce, należy uczynić wszystko, aby bierzmowani, „przez swoją pracę zawodową i przez różnoraką obecność w sferze działalności społecznej, kulturalnej i politycznej, wnosili łaskę Chrystusową i chrześcijańskiego ducha w różne struktury życia świata. Ta obecność chrześcijańska staje się szczególnie potrzebna i pożądana, a zarazem widoczna i skuteczna, zwłaszcza w środkach społecznego przekazu"62. Na tym - jak w duchu Soboru Watykańskiego II uczył już św. Paweł VI - polega misja, przez którą bierzmowani

udzielają światu nowego stopnia uświęcenia. Nie wprowadzają weń przede wszystkim znaków specyficznie świętych i religijnych (które w pewnych formach i okolicznościach mogą również być właściwe), ale porządkują go przez wykonywanie apostolstwa w wierze, nadziei i miłości dla królestwa Bożego, zgodnie ze słowami św. Augustyna: „Kto tak służy bliźniemu, służy Chrystusowi”. To jest świętość, która promieniuje na świat i w świecie. I niech będzie to powołaniem naszych czasów dla nas wszystkich ${ }^{63}$.

\section{BIBLIOGRAFIA}

\section{DOKUMENTY URZĘDU NAUCZYCIELSKIEGO KOŚCIOŁA}

Benedykt XVI, Encyklika Caritas in Veritate, Rzym 2009.

Benedykt XVI, List apostolski w formie „motu proprio” Porta fidei ogłaszający Rok Wiary, Ząbki 2012.

Benedykt XVI, Rozważanie przed modlitwa Anioł Pański (Watykan, 18.02.2007), „L'Osservatore Romano”, 26(2007), nr 4, s. 57.

FrancisZeK, Błogosławieni miłosierni. Słowa do młodych, Kraków 2016.

Instrumentum laboris na XII Zwyczajne Zgromadzenie Ogólne Synodu biskupów, Watykan 2008.

JAN PAWE⿺ II, Encyklika Dominum et Vivificantem, Rzym 1986.

JAN PAWEL II, List apostolski Novo millennio ineunte, Watykan 2001.

${ }^{61}$ Por. KK 31; DA 7; KK 31; D. Chenu, Consecratio mundi, „Znak”, 17(1965) s. 750-761.

${ }^{62}$ E. Weron, Kierownictwo duchowe realizowane przez świeckich $w$ postudze nowej ewangelizacji, „Collectanea Theologica”, 70(2000), nr 1, Biuletyn teologii laikatu (97), s. 160.

${ }^{63}$ Pawee VI, Trwajcie Mocni w wierze, t. II, Kraków 1974, s. 274. 
JAN PAWE⿺ II, Posynodalna adhortacja apostolska Pastores gregis, Rzym 2003.

Katechizm Kościoła Katolickiego, Poznań 2002.

Kongregacja Nauki Wiary, Deklaracja Dominus Iesus, Watykan 2000.

Nadzwyczajny Synod Biskupów, Relacja końcowa, „L’Osservatore Romano”, Dodatek do nr 10-11-12(1985), s. 1-5.

PAWEe VI, Konstytucja apostolska Divinae consortium naturae, „Acta Apostolicae Sedis", 63(1971) s. 657-664.

Pawel VI, Trwajcie Mocni w wierze, t. II, Kraków 1974.

Pielgrzymka Jana Pawła II do Polski. Przemówienia. Dokumentacja. Tekst autoryzowany, Poznań-Warszawa 1979.

Sobór WaTyKańSKi II, Dekret o apostolstwie świeckich Apostolicam actuositatem, w: M. Przybye (red.), Sobór Watykański II, Konstytucje, Dekrety, Deklaracje, Poznań 2002, s. 377-401.

Sobór WaTYKański II, Dekret Soboru Watykańskiego II o misyjnej działalności Kościoła Ad gentes divinitus, w: M. PrzybyŁ (red.), Sobór Watykański II. Konstytucje, dekrety, deklaracje, Poznań 2002, s. 433-471.

Sobór WATYKAŃSKI II, Konstytucja dogmatyczna o Kościele Lumen gentium, w: M. PrzybyŁ (red.), Sobór Watykański II, Konstytucje, Dekrety, Deklaracje, Poznań 2002, s. 104-166.

Sobór WaTYKaŃSKi II, Konstytucja duszpasterska o Kościele w świecie współczesnym Gaudium et spes, w: M. PrzybyŁ (red.), Sobór Watykański II, Konstytucje, Dekrety, Deklaracje, Poznań 2002, s. 526-606.

\section{LITERATURA PRZEDMIOTU}

Balter L., Duch, który woła, w: L. Balter (red.), Powołanie człowieka, t. IV, PoznańWarszawa 1980, s. 35-47.

BALter L., Kapłaństwo Ludu Bożego, Warszawa 1982.

BALter L., Wspólnototwórcza rola liturgii, w: L. BALter (red.), Człowiek we wspólnocie Kościoła, Warszawa 1979, s. 251-268.

BARTNIK Cz.S., Bierzmowanie Kościoła, „Collectanea Theologica”, 48(1978), z. 3, s. 19-30.

BARTNIK Cz.S., Sakrament bierzmowania, „Roczniki Teologiczno-Kanoniczne”, 36(1989), z. 2, s. 45-53.

BARTNIK Cz.S., Istota więzi eklezjalnej, „Studia Płockie”, 23(1995), s. 11-17.

Bronk K., Rozmowa z ks. prof. dr hab. Waldemarem Chrostowskim (Radio Watykańskie - Sekcja Polska, 10.10.2008).

BrzuszeK B., Zobowiazanie wiernych świeckich do apostolstwa, „Collectanea Theologica”, 42(1972), z. 3, s. 57-66. 
Bujak J., Pierwszeństwo Kościoła powszechnego wobec Kościołów lokalnych, „Collectanea Theologica", 76(2006), nr 1, s. 39-55.

Buxakowsiki J., Teologia bierzmowania, „Ateneum Kapłańskie”, 58(1966), t. 69, s. 9-21.

CAmelot P.-T., Bierzmowanie a wylanie Ducha, „Communio”, (1992), z. 2, s. 81-91.

Chenu D., Consecratio mundi, „Znak”, 17(1965), s. 750-761.

Chrostowski W., Duszpasterstwo biblijne jako składnik nowej ewangelizacji, „Collectanea Theologica", 72(2002), nr 3, s. 55-71.

FAlK M., Przygotowanie do sakramentu bierzmowania w katechezie szkolnej w oparciu o wybrane podręczniki do religii, w: J. Stala (red.), Dzisiejszy bierzmowany. Problemy $i$ wyzwania, Kielce 2005, s. 181-203.

Figura M., Specyfika wspólnoty chrześcijańskiej, „Communio”, 23(2003), nr 4, s. 3-20.

FORYCKI R., Z prakseologii apostolstwa stowa, w: M. KowALCZYK (red.), Apostolat stowa Bożego, Biblioteka Instytutu Teologii Apostolstwa 9, Warszawa 2010, s. 249-263.

Hamel E., Wiara a sprawiedliwość społeczna, „Communio”, 1(1981), nr 3, s. 39-51.

JAGodzIŃSKi M., Communio dzięki komunikacji. Teologiczny wymiar teorii komunikatywnego działania w eklezjologii Medarda Kehla SJ, Radom 2002.

Kuuz M., Dynamizm sakramentów chrztu i bierzmowani w służbie budowania Kościoła jako domu, „Liturgia Sacra”, 18(2012), nr 1, s. 71-83.

Kostecki R., Bierzmowanie - sakrament niewykorzystany, „Ateneum Kapłańskie”, 58(1966), t. 69, s. 21-28.

KowAlczyK M., Eklezjalno-apostolski charakter bierzmowania, „Communio”, 12(1992), nr 2, s. 92-102.

KowalczyK M., Parafia wspólnota wspólnot, w: I. ChlopkowsKa, W. Kazimieruk (red.), Chrzest w życiu i misji Kościoła (II), Siedlce 2007, s. 22-37.

KowalczyK M., Teologia i apostolat laikatu, Biblioteka Centrum Teologii Apostolstwa „Pallottianum” w Ołtarzewie 9, Warszawa 2019.

KraKowiak Cz., Z problematyki teologicznej sakramentu bierzmowania, „Roczniki Teologiczno-Kanoniczne", 21(1974), z. 6, s. 38-45.

Krakowiak Cz., Problemy teologiczne i pastoralne podczas prac nad „, Ordo Confirmationis” 1971, „Seminare. Poszukiwania naukowe”, 35(2014), nr 3, s. 57-73.

Królikowski J., Umocnienie i dopetnienie chrztu. Z teologii bierzmowania jako sakramentu wtajemniczenia chrześcijańskiego, w: J. Stala (red.), Dzisiejszy bierzmowany. Problemy $i$ wyzwania, Kielce 2005, s. 44-45.

Kudasiewicz J., Chrzest Chrystusa, „Ateneum Kapłańskie”, 57(1965), t. 67, s. 151-164.

Kunka S., Sakrament bierzmowania a wylanie Ducha, „Teologia i człowiek”, 38(2017), s. 48.

KWIATKOWsKi D., Bierzmowanie sakramentem umacniającym żywa wiarę, która prowadzi do świadectwa $i$ apostolstwa, w: https://opoka.org.pl/biblioteka/M/MS/dk _bierzmowanie.html (dostęp: 12.05.2019). 
LenA M., Źródło życia apostolskiego, „Communio”, 8(1988), s. 144-177.

Miejsce świeckich $w$ Kościele, udziat świeckich $w$ życiu Kościoła, Zintegrowana Baza

Tekstów Papieskich, http://www.nauczaniejp2.pl/ (dostęp 16.07.2019).

NAGy S., Świeccy w komunijnej wspólnocie Kościoła, „Ateneum Kapłańskie”, 82(1990), t. 114 , s. 377-387.

Pyrek J., Czas dla miłości solidarnej, Kraków 1991.

Rak R., Duch Święty jako Dar i Jego dary, w: A.L. Szafrański (red.), Jan Pawet II, Dominum et Vivificantem. Tekst i komentarz, Lublin 1994, s. 137-140.

Ratzinger J., Chrystus, wiara a wyzwanie kultur, „Communio”, 22(2002), nr 1, s. 77-97.

Ratzinger J., Die Einheit der Nationen. Eine Vision der Kirchenväter, SalzburgMünchen 1971.

Ratzinger J., Eklezjologia Soboru Watykańskiego II, w: L. Balter, K. CzulaK, P. GóRALCZYK, J. RATZINGER (red.), Kościót-ekumenizm - polityka, Kolekcja Communio 5, Poznań 1990, s. 13-27.

Ratzinger J., Pielgrzymująca wspólnota wiary. Kościót jako komunia, Kraków 2003.

Sarah R., Duch Święty w Kościele, w: J. BartoszeK, R. Chromy, K. Piechaczek (red.), Program duszpasterski na rok 2018/2019. W mocy Bożego Ducha, Katowice 2018, s. 147-160.

SChoonenberg P., Duch Boży w historii zbawienia, „Communio”, 8(1988), nr 1, s. 76-88.

Semerano M., Le Chiese particolari formate a immagine della Chiesa universale (LG23). Analisi e interpretazioni di una formula, w: N. CIOLA (red.), Servire Ecclesiae. Miscellanea in onore di mons. Pino Scabini, Bologna 1998, s. 303-348.

SKowroneK A, Sakrament bierzmowania; wprowadzenie teologiczne, „Materiały Problemowe", 15(1986) s. 40-43.

SkowroneK A., Z teologii bierzmowania, „Studia Theologica Varsaviensia”, 13(1975), nr 1, s. 25-42.

SKowroneK A., Wokół eklezjalnego aspektu chrztu i bierzmowania, „Ateneum Kapłańskie", 58(1966), t. 69, s. 1-9.

Skrok D.Z., Tendencje współczesnej teologii sakramentu bierzmowania, „Studia Theologica Varsaviensia", 42(2004), nr 2, s. 41-70.

Speyr A. von, Mistica oggettiva, Milano 1975.

SZAFRAŃSKi A.L., Z badań nad charakterem sakramentalnym bierzmowania, „Roczniki Teologiczno-Kanoniczne", 2(1955), s. 29.

Szmulewicz H., Bóg Trójjedyny - źródtem jedności sakramentów wtajemniczenia, „Pedagogika Katolicka”, 2(2008), s. 238-255.

SzYмiк J., Teologia na początek wieku, Katowice-Ząbki 2001. 
Śmigiel W., Teologia sakramentu bierzmowania, w: J. BartoszeK, R. Chromy, K. PIECHACZEK (red.), Jesteśmy napetnieni Duchem Świętym, Katowice 2017, s. 59-81.

Urbański S., Cywilizacja miłości w nauczaniu Jana Pawła II, w: J.M. DoŁęGA (red.), Solidarni z nauczaniem Jana Pawła II, Episteme 1, Olecko 1999, s. 31-45.

Weron E., Apostolstwo katolickie, Poznań 1987.

WERON E., Kierownictwo duchowe realizowane przez świeckich $w$ postudze nowej ewangelizacji, „Collectanea Theologica” 70(2000), nr 1, Biuletyn teologii laikatu (97), s. 160-162.

Weron E., W kontekście VII Synodu Biskupów, „Collectanea Theologica”, 59(1989), z. 3, s. 93-95.

WolańsKi B., Nabożeństwo dziękczynne za sakrament bierzmowania: „Tak i Ja was posyłam”, w: J. BARTOSzeK i in. (red.), Program duszpasterski dla Kościoła w Polsce na rok 2018/2019. W mocy Ducha Bożego. Zeszyt liturgiczny, Katowice 2018, s. 65-69. Wprowadzenie redakcji, w: A. SkreczKo i in (red.), Jesteśmy napetnieni Duchem Świętym, „Studia Teologiczne”, Białystok-Drohiczyn-Lomża 35(2017), s. 5-6.

ZABŁocki J., Świeccy $w$ odnowie porządku doczesnego, „Ateneum Kapłańskie”, 82(1990), t. 114, s. 397-406.

Zuberbier A., Współodpowiedzialność świeckich w zbawczym posłannictwie Kościoła, „Ateneum Kapłańskie”, 82(1990), t. 114, s. 388-393.

ŻĄDŁo A., O bierzmowaniu z inspiracji Programu duszpasterskiego Kościoła w Polsce na rok 2017/2018, „Liturgia Sacra”, 24(2018), nr 1, s. 145-172.

TEOLOGICZNO-EKLEZJALNE ASPEKTY BIERZMOWANIA W ŚWIETLE PROGRAMU DUSZPASTERSKIEGO KOŚCIOŁA W POLSCE NA LATA 2017-2019

S T R E S Z C Z E N I E

Biorąc pod uwagę posoborowe podejście do sakramentologii, oparte na idei Kościoła Chrystusowego jako żywej historii zbawienia, treść artykułu odnosi się do eklezjalnych aspektów programu duszpasterskiego Kościoła w Polsce. Dlatego sakrament bierzmowania jest ujęty w perspektywie eklezjologicznej, bez zbytniego zgłębiania problematyki katechetycznej czy liturgicznej. Najpierw zwraca uwagę na sakrament dojrzałości chrześcijańskiej w aspekcie trwałości Kościoła jako ludu Bożego. W kolejnym paragrafie koncentruje się na uczestnictwie tych, którzy przyjęli sakrament bierzmowania w apostolskich zadaniach ludu Bożego, akcentując zwłaszcza przyjęcie przez nich pełnej odpowiedzialności za losy Kościoła. Zwieńczeniem artykułu jest zobrazowanie ewangelizacji współczesnego świata przez ubogacenie świata nowym obliczem świętości na miarę królestwa Bożego, które przez Chrystusa w mocy Ducha Świętego nieustannie wzrasta wśród ludzi, aż do ostatecznego spełnienia w Bogu, który będzie „wszystkim we wszystkich” (por. 1 Kor 15,24.28).

Słowa kluczowe: wtajemniczenie chrześcijańskie; Chrystus; Kościół; Duch Święty; bierzmowanie; apostolstwo; odnowa świata; Królestwo Boże. 